\title{
Macronutrient and iron limitation of phyto- plankton growth in Hong Kong coastal waters
}

\author{
Ai-Jun Miao", David A. Hutchins ${ }^{2}$, Kedong Yin ${ }^{1,3}$, Fei-Xue Fu ${ }^{2}$, Paul J. Harrison ${ }^{3}$, \\ Wen-Xiong Wang ${ }^{1, *}$
}

\author{
${ }^{1}$ Department of Biology, The Hong Kong University of Science and Technology (HKUST), Clear Water Bay, Kowloon, \\ Hong Kong SAR \\ ${ }^{2}$ College of Marine Studies, University of Delaware, 700 Pilottown Road, Lewes, Delaware 19958, USA \\ ${ }^{3}$ Atmospheric, Marine and Coastal Environment (AMCE) Program, The Hong Kong University of Science and Technology
} (HKUST), Clear Water Bay, Kowloon, Hong Kong SAR

\begin{abstract}
The western side of Hong Kong possesses estuarine characteristics (from the Pearl River estuary) and the eastern side is mainly influenced by the oligotrophic South China Sea, while the southern side has intermediate hydrological characteristics. We investigated the concentrations of dissolved inorganic nutrients and limitations to phytoplankton growth at these 3 locations around Hong Kong. As expected, measurements of dissolved inorganic nitrogen (DIN) and dissolved silicon (DISi) concentrations decreased from the western (DIN: 42.7 to $112 \mu M_{i}$ DISi: 24.1 to $81 \mu \mathrm{M}$ ), to the southern and finally the eastern side $(<5 \mu \mathrm{M}$ for both DIN and DISi). The dissolved inorganic phosphorus (DIP) concentration was relatively constant among all areas $(1.1$ to $1.7 \mu \mathrm{M})$. C:P and N:P ratios in the phytoplankton were much higher than the Redfield ratio at stations on the western and southern sides, and decreased with the addition of P. Therefore, phytoplankton assemblages at these locations were mainly limited by $\mathrm{P}$ as a result of high $\mathrm{N}$ and $\mathrm{Si}$ inputs from the Pearl River relative to P. Our summer bioassay indicated that Fe was not the primary limiting element in the estuarine area. Although P stimulation of phytoplankton growth was also observed on the eastern side, additions of N, P, Si and Fe indicated that all of these nutrients except Fe had a strong effect on growth. C:Si and N:Si ratios on the eastern side were $>>6.6: 1$ and $>>1: 1$, respectively, but decreased with the addition of Si. Furthermore, 'luxury uptake' of P and Si was observed after replenishment of these nutrients. Thus, it was hypothesized that phytoplankton on the eastern side were limited by several nutrients sequentially in the following order: $\mathrm{P}>\mathrm{Si}>\mathrm{N} / \mathrm{Fe}$. A shift in limitation from one nutrient to another may frequently take place, as concentrations of all these nutrients are low. Furthermore, temporal and spatial variations of nutrient concentration and phytoplankton growth limitation were also observed in the estuary.
\end{abstract}

KEY WORDS: Macronutrient $\cdot$ Iron $\cdot$ Phytoplankton $\cdot$ Limitation $\cdot$ Pearl River Estuary Resale or republication not permitted without written consent of the publisher

\section{INTRODUCTION}

A major aim of research into estuarine, coastal, and oceanic waters is to assess the extent to which nutrients limit primary production. There is a long-standing debate over which nutrient limits primary production in the ocean: nitrogen regulation (biological view) or phosphorus regulation (geochemical view) (Tyrrell 1999). More recently iron has been identified as a potential limiting nutrient to primary produc- tion in many parts of the ocean, especially in high nutrient low chlorophyll (HNLC) areas (Martin \& Fitzwater 1988), and possibly also in estuaries and some coastal areas (Hutchins \& Bruland 1998, Zhang 2000, Lewitus et al. 2004). Silicon, as an important compositional element in diatoms, was also found to potentially limit new production in the open ocean, coastal waters, and estuaries (Dugdale et al. 1995, Boyd et al. 1999, de Baar et al. 1999, Wu \& Chou 2003). 
Furthermore, primary production can be limited not only by a single nutrient, but also by 2 or more nutrients simultaneously (Mills et al. 2004). It has been suggested that co-limitation can be divided into 3 different types, including multiple-nutrient, biochemical, and community co-limitations (Arrigo 2005). Temporal and spatial variations in nutrient limitation have been observed in a single area (Thompson 1998, Fisher et al. 1999). In fact, the actual nutrient(s) that limits the growth of the phytoplankton assemblage in an area at a specific time is rather dependent on multiple chemical, physical, physicochemical, hydrological and biological processes.

Hong Kong has a complex hydrological setting. The western side is an estuary, which receives a high riverine discharge from the Pearl River. The Pearl River is the second largest river in China and drains an area of $452000 \mathrm{~km}^{2}$ (Zhao 1990). It discharges $3.5 \times 10^{11} \mathrm{~m}^{3}$ $\mathrm{yr}^{-1}$ of freshwater into the South China Sea. Eighty percent of this discharge occurs during the wet season (April to September), and is characterized by a high

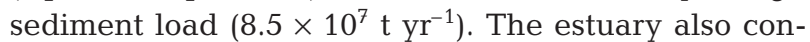
tains large amounts of nutrients, with dissolved inorganic nitrogen (DIN) concentrations ranging from 60 to $100 \mu \mathrm{M}$ and dissolved silicon (DISi) concentrations ranging from 100 to $150 \mu \mathrm{M}$ (Zhang 2000). The freshwater discharge produces an estuarine plume, while saline water from the South China Sea forms a wedge northward. This is evidenced by salinity and nutrient profiles on the western and eastern sides (Yin et al. 2001). As the estuarine plume flows into the South China Sea, it often forms a coastal plume and spreads to the southern side of Hong Kong due to the southwest monsoon prevalent in summer (Yin 2002). Thus, the coastal water on the southern side of Hong Kong may also be affected by riverine discharge from the Pearl River.

Due to the relatively high $\mathrm{N}$ and $\mathrm{Si}$ input from the Pearl River, $\mathrm{P}$ was thought to be the main limiting nutrient in the estuarine-influenced waters (Yin et al. 2001). Zhang (2000) reported that the phytoplankton species in this area showed the greatest response to the exogenous Fe and concluded that, in addition to $\mathrm{P}$, primary production in this area was also limited by $\mathrm{Fe}$ and some other trace metals. Thus, further investigations are required to determine the temporal and spatial variability of potential Fe and $\mathrm{P}$ limitation for phytoplankton growth in the Pearl River estuary.

Conditions are completely different for coastal water on the eastern side of Hong Kong. The riverine discharge has little effect on this side and the water here has similar characteristics to the oligotrophic South China Sea. Concentrations of all the nutrients and phytoplankton biomass are very low (Yung et al. 2001, Yin 2002). For example, the average DIN and DISi con- centrations in June and July from 1991 to 2000 were $<5 \mu \mathrm{M}$, and dissolved inorganic phosphorus (DIP) was $<0.5 \mu \mathrm{M}$ (Yin 2002). Yin et al. (2001) found that primary production there might be limited by $\mathrm{N}$, which is often observed for the oligotrophic South China Sea waters (Wu et al. 2003). The potential $\mathrm{N}$ limitation on this side may also be evidenced by the observation of diazotroph Trichodesmium sp.. It is also possible that phytoplankton in this area may be co-limited by more than 1 nutrient, as all nutrients here are found in low concentrations (Yin et al. 2000).

In this study, we further investigated the concentrations of dissolved inorganic nutrients and examined the limitation of phytoplankton growth on the 3 different sides of Hong Kong with different hydrological characteristics. The objectives were to examine whether Fe limited primary production in these areas and whether there is any nutrient co-limitation, especially on the eastern side. As the riverine input varies temporally, we expected to observe some temporal and spatial variations in both nutrient concentration and phytoplankon growth limitation on the western and southern sides.

\section{MATERIALS AND METHODS}

Sampling sites. Eight stations were sampled in Hong Kong waters. Four of them were on the western side (Stns 1, 2, 5 and 6), two on the southern side (Stns 7 and $8)$, and the other two on the eastern side (Stns 3 and 4), as shown in Fig. 1. Stns 1 and 2 were close to Stns 5 and 6, respectively. Sample collection from Stns 1 and 2 was conducted about 3 wk earlier than from Stns 5 and 6 (June 23 vs. July 12, 2004). The waters on the 3 sides had completely different hydrological characteristics, with salinities ranging from 7.8 to $32.3 \mathrm{psu}$ and turbidities ranging from $\sim 0$ to 7.0 NTU (nephelometer turbidity units) (Table 1).

Nutrient addition experiments. Four cruises were conducted between June 23 and July 20, 2004, each sampling two of the eight stations (i.e. Stns 1 and 2 during the first cruise, and Stns 7 and 8 during the 4th cruise) (Table 1). In order to collect water samples for Fe addition experiments and avoid potential trace metal contamination, a small rubber raft or wooden boat was used and paddled against the current at each station. A person in the front of the boat wearing gloves opened and filled experimental polycarbonate bottles (1 to 2 l) just below the water surface and collected water samples. All bottles were previously soaked in $10 \% \mathrm{HCl}$, rinsed 6 times with Milli-Q water (18.0 M $\Omega$ ), and then rinsed 3 times again with in situ water from each station.

After collection, water samples were covered with black bags and sent immediately to the laboratory, and 


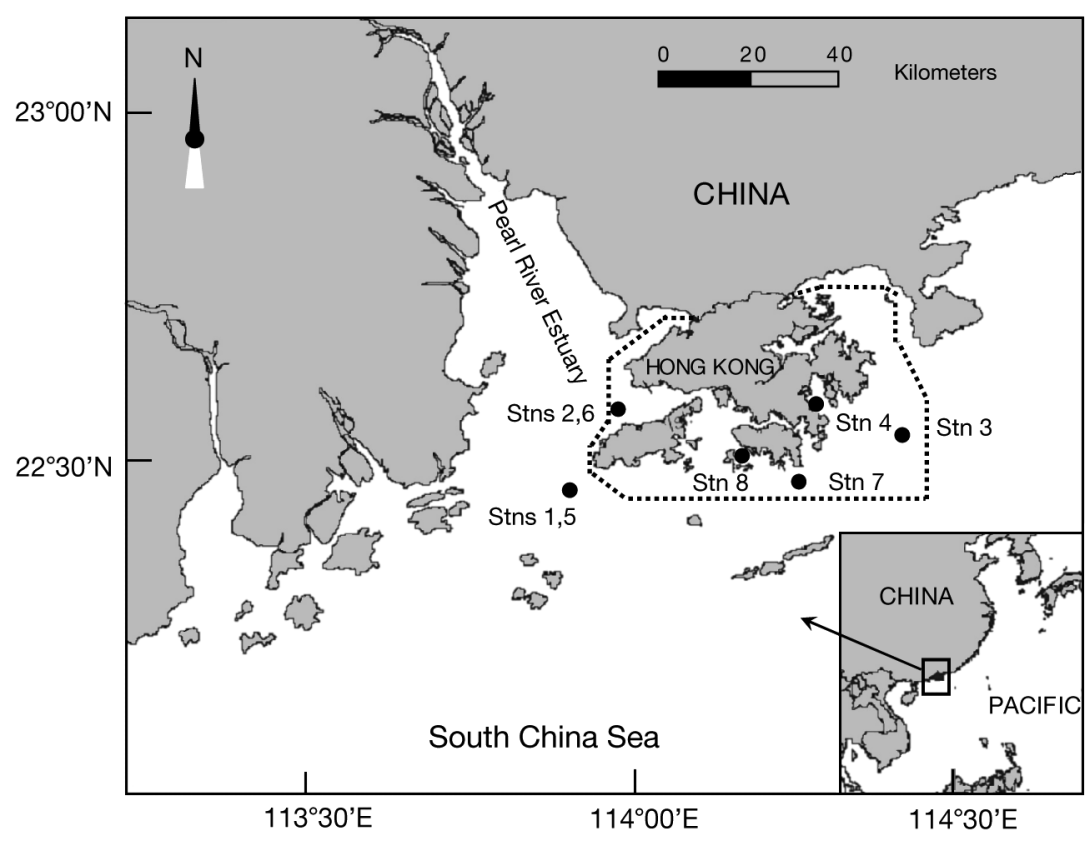

Fig. 1. Study area showing sampling stations. Dashed line around Hong Kong represents territorial boundary of the Special Administration Region of Hong Kong tion treatments with a TD-700 fluorometer every day. The first incubation lasted $3 \mathrm{~d}$ (Stns 1 and 2), and it was found that phytoplankton biomass declined after 2 d. Therefore, a 2 d incubation was used for the other stations.

Parameters measured. The dissolved oxygen (DO), temperature, salinity, and turbidity of the surface water at each station were measured with a YSI 6600. Concentrations of dissolved nutrients were analyzed with a Skalar San Plus Autoanalyzer. Nitrate plus nitrite $\left(\mathrm{NO}_{3}{ }^{-}\right.$ $\left.+\mathrm{NO}_{2}{ }^{-}\right)$and ammonium $\left(\mathrm{NH}_{4}{ }^{+}\right)$were determined using the methods developed by Wood et al. (1967) and Slawyk \& MacIsaac (1972), respectively. DIP and DISi concentrations were measured following the method of Hager et al. (1968) and Armstrong et al. (1967). All the water samples were pre-filtered with $0.22 \mu \mathrm{m}$ polycarbonate membrane before the nutrient analyses.

A sub-sample of about $100 \mathrm{ml}$ from

the nutrient addition experiments were then conducted. The water samples were not pre-filtered before the nutrient addition to avoid exclusion of large phytoplankton cells, and thus contained the entire plankton community including phytoplankton and associated microzooplankton. However, mesozooplankton were not observed in the bottles. There were 7 addition treatments with 3 replicates for all stations (except Stn 1) including the unamended control, $\mathrm{NO}_{3}^{-}(+\mathrm{N}), \mathrm{PO}_{4}{ }^{3-}(+\mathrm{P})$, $\mathrm{SiO}_{4}{ }^{3-}(+\mathrm{Si}), \mathrm{Fe}^{3+}(+\mathrm{Fe})$, all 4 nutrients $(+\mathrm{All})$, and all nutrients except $\mathrm{Fe}^{3+}(+\mathrm{All}-\mathrm{Fe})$ treatments. Stn 1 was not tested with the +All treatment. The water sample in each bottle served as 1 replicate for 1 of the 6 or 7 treatments at each station. The nutrient concentrations added were 100,5 , and $100 \mu \mathrm{M}$ for $\mathrm{N}, \mathrm{P}$, and $\mathrm{Si}$, respectively, and $10 \mathrm{nM}$ for Fe, except that $20 \mu \mathrm{M}$ Si was used for Stns 7 and 8 . All the nutrient additions were performed in a Class 100 laminar flow cabinet to avoid inadvertent trace metal contamination. After nutrient addition, the bottles were capped and sealed with electrical insulation tapes and put in a tank on a building roof. The temperature (ca. $29^{\circ} \mathrm{C}$ ), which was the average surface water temperature in this season, was kept constant with circulated tap water during the incubation period. The tank was covered with 3 layers of neutral density screens $(70 \%$ reduction of ambient light) to avoid light inhibition (Mallin \& Paerl 1992) and mimic the average light intensity of the mixed layer in the water column. One additional replicate for each treatment (besides the 3 replicates) was used to monitor the in vivo fluorescence of the different nutrient addi- each bottle was filtered through a pre-combusted 25 $\mathrm{mm}$ Whatman GF/F membrane and stored frozen $\left(-20^{\circ} \mathrm{C}\right)$, then dried at $50^{\circ} \mathrm{C}$ for about $24 \mathrm{~h}$ prior to particulate organic carbon and nitrogen (POC and PON) analyses. POC and PON concentrations were quantified with a CHNS/O elemental analyzer (Perkin Elmer PE 2400 Series II) using acetanilide $\left(\mathrm{C}_{8} \mathrm{H}_{9} \mathrm{NO}\right)$ as the standard. The samples were not decarbonated before the elemental analysis, and thus some particulate inorganic carbon may have also been included in our POC measurement. However, the inorganic carbon likely made a negligible contribution to the total particulate carbon, as calcifying organisms like coccolithophores are usually rare in this region. For particulate organic phosphorus (POP) determinations, another $100 \mathrm{ml}$ subsample was filtered through a pre-combusted GF/F filter, rinsed twice with $2 \mathrm{ml}$ of $0.17 \mathrm{M} \mathrm{Na}_{2} \mathrm{SO}_{4}$, placed in a combusted glass scintillation vial with $2 \mathrm{ml}$ of 0.017 $\mathrm{M} \mathrm{MgSO}_{4}$, and evaporated to dryness at $95^{\circ} \mathrm{C}$. The organic matter was converted to inorganic phosphate by combustion in a muffle furnace at $460^{\circ} \mathrm{C}$ for $2 \mathrm{~h}$. After cooling, $5 \mathrm{ml}$ of $0.2 \mathrm{M} \mathrm{HCl}$ was added to each tightly capped vial and heated at $80^{\circ} \mathrm{C}$ for $30 \mathrm{~min}$. The orthophosphate was then determined by colorimetric analysis using a spectrophotometer after rehydration of the sample (Solorzano \& Sharp 1980, Lebo \& Sharp 1992). Biogenic silica (BSi) of each replicate was measured with $100 \mathrm{ml}$ sample filtered through a $1 \mu \mathrm{m}$ polycarbonate membrane. The biogenic Si was extracted with $\mathrm{NaOH}$ in a boiling water bath. After neutralization with $\mathrm{HCl}$, the DISi concentration was measured 
colorimetrically (Strickland \& Parsons 1968, Brzezinski $\&$ Nelson 1995). Part of the lithogenic Si (LSi) may have been leached with this method (Ragueneau et al. 2005). However, no satisfying method was available to correct this mineral interference when our experiments were performed.

For the measurement of chl $a_{1} 50 \mathrm{ml}$ samples were filtered through 0.22 and $5.0 \mu \mathrm{m}$ polycarbonate filters, which represented the total and large size fraction of $\mathrm{chl}$ a. Chl was extracted for $24 \mathrm{~h}$ in $90 \%$ acetone and kept in the dark at $-20^{\circ} \mathrm{C}$. Fluorescence (before and after acidification with $10 \% \mathrm{HCl}$ ) was then measured with a TD-700 fluorometer. The chl a concentrations were calculated as described by Parsons et al. (1984).

Another $50 \mathrm{ml}$ sample was preserved with Lugol's solution for the identification of dominant phytoplankton species. Subsequently, a $10 \mathrm{ml}$ sub-sample from each treatment was settled in a modified Utermöhl sedimentation chamber for at least $24 \mathrm{~h}$ (Yung et al. 2001). Phytoplankton species were then identified and cell numbers were qualitatively estimated under an inverse microscope.

Statistical analysis. Significant differences between treatments at the $\mathrm{p}<0.05$ level were determined using a $t$-test or 1-way ANOVA with post hoc multiple comparisons (Tukey's test).

\section{RESULTS}

\section{DO, salinity, temperature, turbidity and dissolved and particulate elemental contents}

The DO, salinity, temperature, and turbidity of the surface water at each station are shown in Table 1.
As expected, the salinity of the stations on the western and southern sides was lower than that of stations on the eastern side $(<25$ vs. $>30 \mathrm{psu})$. Although Stns 1 and 2 and Stns 5 and 6 were all located in the estuary, the salinity of Stns 1 and 2 (22.9 and 17.3 psu respectively) was much higher than Stns 5 and 6 (7.8 psu for both), due to the difference in sampling time (ca. 3 wk interval). A reverse trend was observed for turbidity, with stations on the western side having higher turbidity than stations on the southern and eastern sides. The turbidity of Stns 1,2, 5 and 6 ranged from 5.9 to $7.0 \mathrm{NTU}$, and $<0.5 \mathrm{NTU}$ for Stns 3 and 4. Similarly, Stns 5 and 6 (7.0 NTU for both) had relatively higher turbidity than Stns 1 and 2 (6.2 and 5.9 NTU respectively). No consistent trends were observed for DO and temperature among different stations.

The initial DIN, DIP, and DISi concentrations in the water samples collected from different stations are listed in Table 1. Ammonium $\left(\mathrm{NH}_{4}^{+}\right)$concentrations were quite low $(<0.1 \mu \mathrm{M})$ and were thus neglected in our calculation of DIN. DIN and DISi showed marked variation among different stations. Concentrations of DIN and DISi were highest at Stns 5 and 6. The lowest DIN and DISi concentrations were found at Stns 3 and 4 on the eastern side. Both nutrient concentrations were $<4 \mu \mathrm{M}$. In contrast to DIN and DISi, DIP concentrations were similar among all 8 stations, ranging from 1.1 to $1.7 \mu \mathrm{M}$. DIN and DISi concentrations were much lower at Stns 1 and 2 than at Stns 5 and 6, even though all these stations were located in the estuary. Stn 2 was located upstream in the estuary relative to Stn 1, and it had higher DIN and DISi concentrations. However, the concentration difference between Stns 5 and 6 was smaller.

Table 1. Sampling date, dissolved oxygen content (DO, $\left.\mathrm{mg} \mathrm{l}^{-1}\right)$, salinity (psu), temperature $\left({ }^{\circ} \mathrm{C}\right)$, turbidity (NTU), initial dissolved inorganic and particulate elemental contents $\left(\mu \mathrm{mol} \mathrm{l}^{-1}\right)$ for each station. All samples taken in 2004. Values are mean \pm SD $(\mathrm{n}=3)$. DIN and DIP: dissolved inorganic nitrogen and phosphate, respectively; DISi: dissolved silicon; POC, PON and POP: particulate organic carbon, nitrogen and phosphate, respectively; BSi: biogenic silica $\left(\mu \mathrm{M} \mathrm{l}^{-1}\right)$; nd: not determined. Values for the first 4 parameters were the same for Stns 5/6 and 7/8 because of high water flow velocities

\begin{tabular}{|c|c|c|c|c|c|c|c|c|}
\hline \multirow{2}{*}{$\begin{array}{l}\text { Date: } \\
\text { Stn: }\end{array}$} & \multicolumn{2}{|c|}{ June 23} & \multicolumn{2}{|c|}{ June 28} & \multicolumn{2}{|c|}{ July 12} & \multicolumn{2}{|c|}{ July 20} \\
\hline & 1 & 2 & 3 & 4 & 5 & 6 & 7 & 8 \\
\hline DO & $10.7 \pm 0.6$ & $7.9 \pm 0.3$ & $9.7 \pm 1.2$ & $9.0 \pm 0.6$ & \multicolumn{2}{|c|}{$8.6 \pm 0.3$} & \multicolumn{2}{|c|}{$9.0 \pm 0.4$} \\
\hline Salinity & $22.9 \pm 0.5$ & $17.3 \pm 0.05$ & $31.7 \pm 1.4$ & $32.3 \pm 0.01$ & \multicolumn{2}{|c|}{$7.8 \pm 0.01$} & \multicolumn{2}{|c|}{$23.1 \pm 0.1$} \\
\hline Temperature & $30.1 \pm 0.1$ & $30.2 \pm 0.2$ & $29.7 \pm 0.1$ & $31.0 \pm 0.03$ & \multicolumn{2}{|c|}{$29.5 \pm 0.01$} & \multicolumn{2}{|c|}{$27.3 \pm 0.01$} \\
\hline Turbidity & $6.2 \pm 0.6$ & $5.9 \pm 0.5$ & $0.2 \pm 0.5$ & $-0.3 \pm 0.4$ & \multicolumn{2}{|c|}{$7.0 \pm 0.3$} & \multicolumn{2}{|c|}{$2.6 \pm 0.1$} \\
\hline DIN & $42.7 \pm 0.34$ & $71.6 \pm 0.27$ & $3.40 \pm 0.75$ & $2.57 \pm 0.33$ & $103.4 \pm 2.98$ & $112.8 \pm 0.52$ & $33.7 \pm 2.16$ & $33.7 \pm 0.83$ \\
\hline DISi & $24.1 \pm 0.47$ & $50.0 \pm 0.50$ & $2.48 \pm 0.14$ & $2.37 \pm 0.07$ & $74.1 \pm 1.51$ & $80.7 \pm 1.96$ & $22.6 \pm 1.14$ & $27.4 \pm 1.39$ \\
\hline DIP & $1.49 \pm 0.12$ & $1.70 \pm 0.07$ & $1.60 \pm 0.12$ & $1.74 \pm 0.16$ & $1.12 \pm 0.18$ & $1.41 \pm 0.14$ & $1.62 \pm 0.17$ & $1.62 \pm 0.07$ \\
\hline POC & nd & nd & $35.3 \pm 0.5$ & $36.3 \pm 0.5$ & $39.8 \pm 4.3$ & $37.0 \pm 3.1$ & $102.8 \pm 6.3$ & $97.4 \pm 5.1$ \\
\hline PON & nd & nd & $4.4 \pm 0.1$ & $3.7 \pm 0.3$ & $7.8 \pm 0.9$ & $7.0 \pm 0.4$ & $15.6 \pm 0.5$ & $14.3 \pm 0.5$ \\
\hline POP & $0.77 \pm 0.03$ & $0.42 \pm 0.01$ & $0.10 \pm 0.01$ & $0.13 \pm 0.01$ & $0.39 \pm 0.04$ & $0.40 \pm 0.02$ & $0.45 \pm 0.01$ & $0.38 \pm 0.2$ \\
\hline $\mathrm{BSi}$ & $14.7 \pm 0.4$ & $5.6 \pm 0.1$ & $3.3 \pm 0.02$ & $2.2 \pm 0.03$ & $4.6 \pm 0.2$ & $6.7 \pm 0.3$ & $22.0 \pm 1.1$ & $15.1 \pm 0.7$ \\
\hline
\end{tabular}


Initial particulate elemental contents (i.e. POC, PON, POP, and BSi) are also shown in Table 1. Stns 7 and 8 usually had the highest values, with the exception that their POP concentrations were similar to those in the estuarine area (Stns 1, 2, 5, and 6), which may be due to their relatively high dissolved nutrient concentrations and stationary environment. This was further evidenced by lower POP and BSi concentrations at Stn 2 relative to Stn 1, as Stn 2 is closer to the Pearl River mouth and water flowed faster there. Furthermore, this spatial variation was not observed at Stns 5 and 6, which were also located in the estuarine area but had a higher water flow speed.
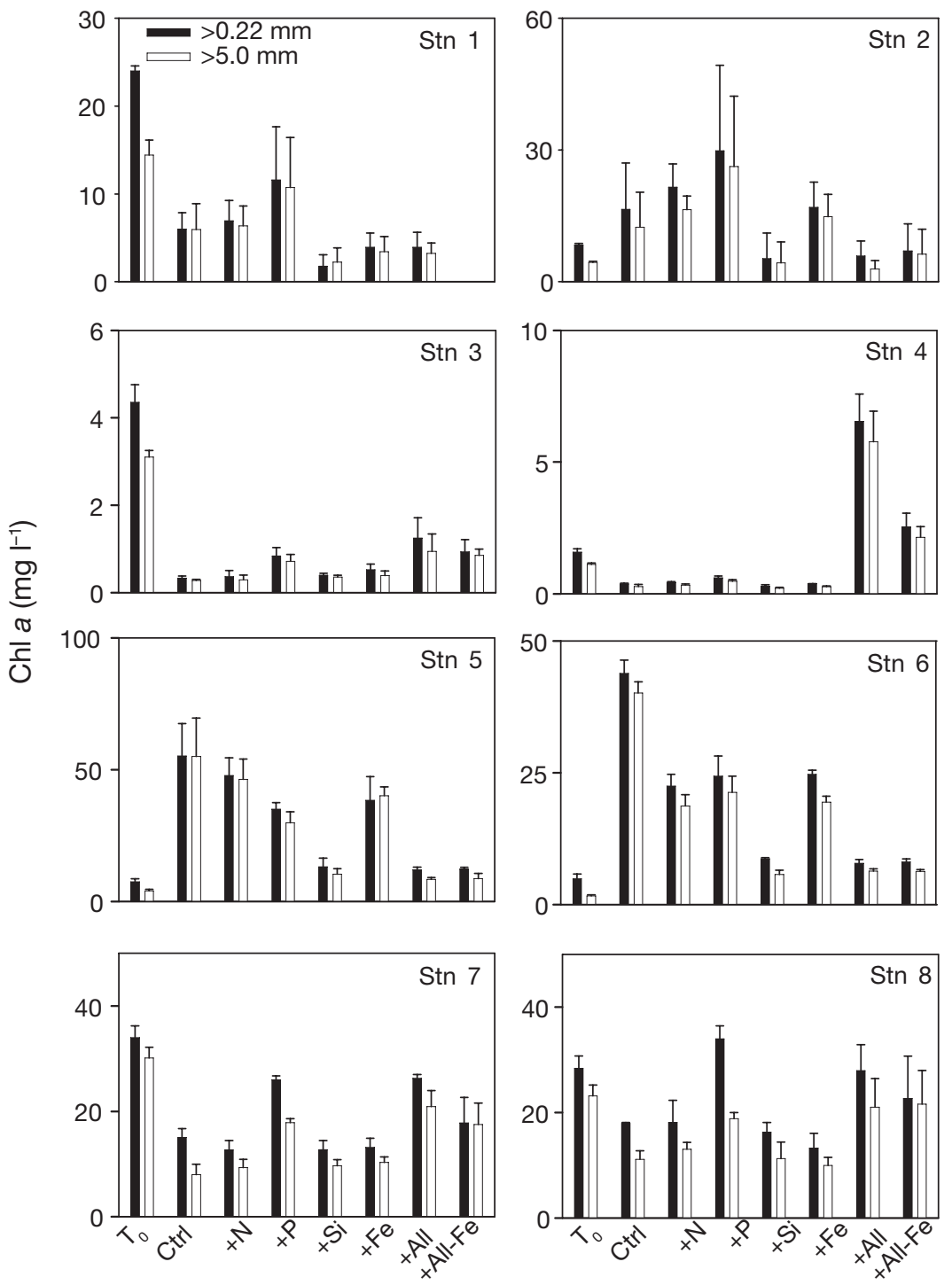

Treatments

Fig. 2. Initial $\left(T_{0}\right)$ and final chl a concentrations for phytoplankton with different nutrient addition treatments $\left(\mathrm{Ctrl},+\mathrm{N}_{1}+\mathrm{P}_{1}+\mathrm{Si},+\mathrm{Fe},+\mathrm{All},+\mathrm{All}-\mathrm{Fe}\right)$ and size fractionation $(>0.22$ and $>5.0 \mu \mathrm{m})$ at each station. Values are mean $\pm \mathrm{SD}(\mathrm{n}=3)$

\section{Chl a concentration and phytoplankton composition}

The initial and final chl a concentrations ( $>0.22$ [total chl a] and >5.0 $\mu \mathrm{m}$ [large size-class chl a]), for the different nutrient addition treatments of the 8 stations are shown in Fig. 2. Most of the total chl a concentrations were accounted for by the large size-class phytoplankton at nearly all stations. Their responses to different nutrient additions were similar. Therefore, only total chl a concentrations are discussed in the following sections, unless otherwise noted, to be consistent with the total parculate elemental contents measured. The initial chl a concentrations at Stns 3, 4, 7, and 8 were unexpectedly higher than the final ones. This suggested that the light intensity used during the incubation period might be higher than the average in situ irradiance the phytoplankton are usually exposed to, as a common response to increasing light levels is a decrease in chl a cell $^{-1}$ (Raven 1990). Particulate elemental contents did not decrease at these stations, indicating that the chl a decreases were probably due to photoadaptation, not to actual declines in biomass. However, at Stn 1, phytoplankton abundance did begin to decline abruptly after $2 \mathrm{~d}$, and the lower final chl a concentrations in this experiment may indicate the breakage of photosynthetic systems.

The initial chl a concentrations varied between different stations. Highest concentrations were observed at Stns 7 and 8 (34.0 and $28.4 \mu \mathrm{g} \mathrm{l}^{-1}$, respectively), while chl a concentrations were the lowest at Stns 3 and 4 (4.4 and $1.6 \mu \mathrm{g} \mathrm{l}^{-1}$, respectively). However, different trends were observed after 2 or $3 \mathrm{~d}$ of incubation. Chl a concentrations in the control treatments of stations on the western estuarine side (especially Stns 5 and 6) turned to be the highest (55.3 and $43.9 \mathrm{\mu g} \mathrm{l}^{-1}$, respectively), consistent with the highest dissolved nutrients concentrations at these stations. Although phytoplankton declined after $3 \mathrm{~d}$ incubation at Stns 1 and 2, they still had relatively high chl a concentrations (e.g. $16.5 \mu \mathrm{g} \mathrm{l}^{-1}$ at Stn 2). Conversely, the lowest chl a concentrations were still observed at Stns 3 and 4 located on the eastern side of Hong Kong, with concentrations of 0.34 and $0.37 \mu \mathrm{g} \mathrm{l}^{-1}$, respectively.

The nutrient additions had notable effects on phytoplankton growth at these stations. P-stimulated growth was ob- 
served at most stations (Stns 1-4, 7 and 8). Chl a concentrations in the $+\mathrm{P}$ treatments at Stns 7 and 8 were 26.0 and $33.9 \mu \mathrm{g} \mathrm{l}^{-1}$ as compared with 15.0 and $17.9 \mu \mathrm{g} \mathrm{l}^{-1}$ in the control treatments. P-stimulated phytoplankton growth was further evidenced by significantly higher chl a concentrations in the +All and +All-Fe treatments at Stns 3, 4, 7 , and 8 ( $\mathrm{p}<0.05)$.

In contrast to $\mathrm{P}$, no stimulation effects were observed after addition of $\mathrm{N}$ or $\mathrm{Si}$ alone. No difference was observed for chl a concentration between the control and $+\mathrm{N}$ treatments at all stations except Stn 6. Furthermore, $\mathrm{Si}$ addition even inhibited cell growth at stations in the

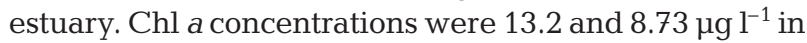
the + Si treatments at Stns 5 and 6, as compared with 55.3 and $43.9 \mathrm{\mu g}^{-1}$ in the control treatments. Similar inhibition effects were also observed in the +All and +All-Fe treatments at these 4 stations. However, $\mathrm{Si}$ inhibition effects were not observed at Stns 3 and 4 when the same amount of $\mathrm{Si}(100 \mu \mathrm{M})$ was added from the same Si stock. The chl a concentrations were 0.40 and $0.28 \mu \mathrm{g} \mathrm{l}^{-1}$ in the + Si treatments, as compared with 0.34 and $0.37 \mu \mathrm{l}^{-1}$ in the control treatments of these 2 stations. This was further evidenced by the much higher chl a concentrations in the +All (1.25/6.54 $\left.\mathrm{gg} \mathrm{l}^{-1}\right)$ and +All-Fe (0.93/2.53 $\mu \mathrm{g}$ $\mathrm{l}^{-1}$ ) treatments compared to the control at Stns 3 and 4 . No Si inhibition effects were observed at Stns 7 and 8, which had lower concentrations of added Si (i.e. 20 vs. $100 \mu \mathrm{M})$.

Although the addition of $\mathrm{P}$ only stimulated cell growth at Stns 3 and 4, a much more significant increase was observed with the addition of all nutrients $(p<0.05)$. When all nutrients were added, chl a concentrations were about 3.7 and 17.7 times higher than the control treatments, as compared with 2.5 and 1.6 times for the $+\mathrm{P}$ treatments. The growth stimulation in the +All-Fe treatments was also higher than the $\mathrm{P}$ addition (2.7 and 6.8 times vs. 2.5 and 1.6 times). But it was less significant than +All treatment, especially at Stn $4(\mathrm{p}<0.05)$. Hence, other nutrients i.e. N, Si or Fe could co-limit cell growth at Stns 3 and 4 .

The dominant phytoplankton species at all 8 stations are shown in Table 2 . The species compositions at the beginning and end of the incubations were similar

Table 2. Dominant algal species at each of the 8 stations

\begin{tabular}{|ll|}
\hline Stn & \multicolumn{1}{c|}{ Main algal species } \\
\hline 1 & Asterionella japonica; Skeletonema costatum \\
2 & $\begin{array}{l}\text { S. costatum; Pseudonitzschia pungens; } \\
\text { Chaetoceros sp.; A. japonica }\end{array}$ \\
$3 \& 4$ & $\begin{array}{l}\text { Chaetoceros sp.; Leptocylindrus danicus; } \\
\text { P. pungens; Prorocentrum sp. }\end{array}$ \\
$5 \& 6$ & Thalassiosira rotula; S. costatum \\
$7 \& 8$ & $\begin{array}{l}\text { S. costatum; P. pungens; } \\
\text { A. japonica; Chaetoceros sp. }\end{array}$ \\
&
\end{tabular}

among all stations. Picoplankton was not identified, as the large size-class phytoplankton accounted for most of total chl a. Diatoms were dominant at all stations, but the species composition varied greatly among different stations of the western, southern, and eastern sides. Even for the estuarine stations, species composition varied between Stns 1 and 2 (June 23) and Stns 5 and 6 (July 12). Although Stns 1 and 2 were sampled on the same cruise, the algal species changed between these 2 stations due to the fact that Stn 2 was closer to the Pearl River. No difference was observed between Stns 5 and 6 . While algal number was only estimated qualitatively, the biomass differences among stations had a similar trend to changes in chl a. Very high cell density was observed at stations on the western and southern sides, whereas cell density at stations on the eastern side was much lower. Si-inhibition of cell growth at Stns 1, 2, 5 and 6 was also evidenced by much lower cell densities in all $\mathrm{Si}$ addition treatments.

\section{Cellular C:N, C:P, C:Si, N:P, and N:Si ratios}

The final POC, PON, BSi and POP measurements for the different nutrient addition treatments at all 8 stations showed trends that were similar to those of chl a (data not shown), except that they were higher than initial values obtained from all stations. This supports our suggestion that the chl a decrease at Stns 3, 4, 7, and 8 was due to high light acclimation of the phytoplankton. At the same time, Si-inhibition effects were also observed at stations in the estuarine area. While final POC and PON concentrations in all $\mathrm{Si}$ addition treatments were only about 42 to $46 \%$ and 52 to $56 \%$ of those in control treatments, they were comparable among the

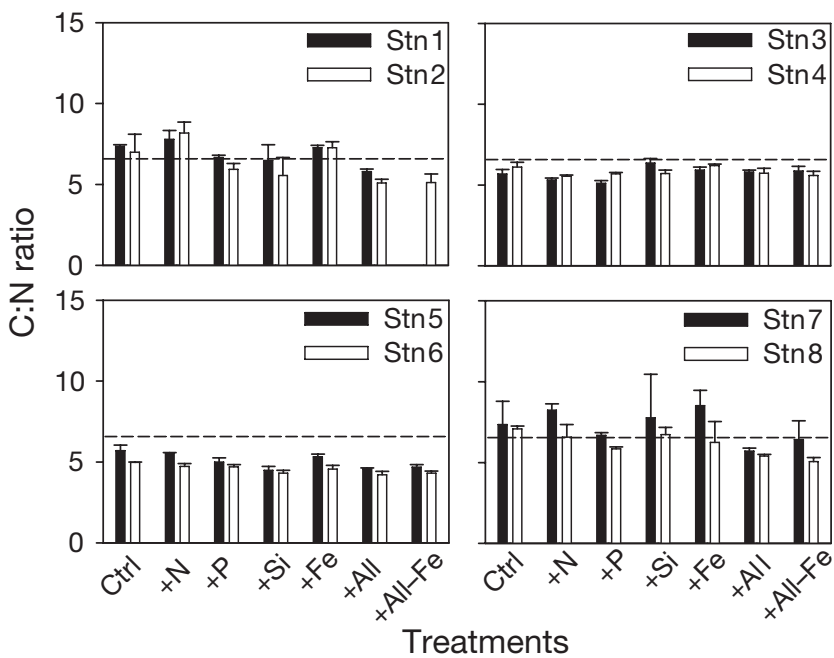

Fig. 3. Particulate organic carbon to nitrogen ratios for different nutrient addition treatments $\left(\mathrm{Ctrl}_{1}+\mathrm{N},+\mathrm{P},+\mathrm{Si},+\mathrm{Fe}\right.$, + All, + All-Fe) at each station after a 2 or $3 \mathrm{~d}$ incubation. Dashed lines: Redfield ratio for $\mathrm{C}: \mathrm{N}$. Values are mean $\pm \mathrm{SD}(\mathrm{n}=3)$ 
other 3 treatments (i.e. $+\mathrm{N},+\mathrm{P},+\mathrm{Fe})$. Their ratios $(\mathrm{C}: \mathrm{N}$, $\mathrm{C}: \mathrm{P}, \mathrm{C}: \mathrm{Si}, \mathrm{N}: \mathrm{P}$, and $\mathrm{N}: \mathrm{Si}$ ) in different nutrient addition treatments after incubation are shown in Figs. 3 to 7. The initial values of these ratios were similar to those of the control treatment and are not shown in the figures.

$\mathrm{C}: \mathrm{N}$ ratios were relatively constant for the different nutrient addition treatments among all stations (Fig. 3), and ranged from 5.1:1 to $7.8: 1$ and were close to the Redfield ratio of C:N (6.6:1). In contrast, C:P showed large variations among different treatments as well as among different stations (Fig. 4). For all stations except Stn 6, the C:P ratio of control treatments was higher than 106:1 (the Redfield ratio). C:P was 281:1 and 265:1 in control treatments at Stns 7 and 8, respectively, while it was close to the Redfield ratio at Stn 6 (85:1 vs. 106:1). For those stations where C:P ratios of control treatments were much higher than the Redfield ratio, C:P approached 106:1 in the treatments with the addition of $\mathrm{P}$. C:P ratios for all $\mathrm{P}$ addition treatments, including $+\mathrm{P},+$ All, and + All-Fe treatments, ranged from 96:1 to $143: 1$ as compared with $281: 1$ and $265: 1$ in the control treatments of Stns 7 and 8.

Compared with the C:P ratio, the C:Si ratio was less variable at most stations (Stns 1, 2, 5, 6 and 7) (Fig. 5). However, these ratios showed a remarkable difference to different nutrient addition treatments at Stns 3 and 4. For those treatments without the addition of $\mathrm{Si}, \mathrm{C}: \mathrm{Si}$ ratios ranged from 13.9:1 to 17.4:1. There was a notable decrease in this ratio following the addition of Si (i.e. + Si, +All, and +All-Fe treatments), with values ranging from $1.35: 1$ to $3.38: 1$.

Consistent with the C:P ratio, the $\mathrm{N}: \mathrm{P}$ ratio in the control treatments was much higher than the Redfield

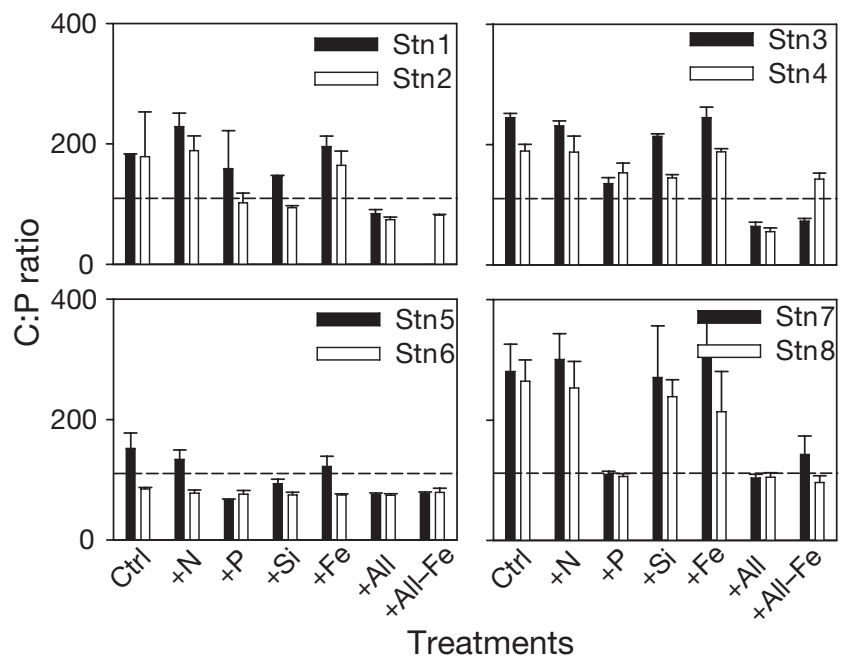

Fig. 4. Particulate organic carbon to phosphorus ratios for different nutrient addition treatments $(\mathrm{Ctrl},+\mathrm{N},+\mathrm{P},+\mathrm{Si},+\mathrm{Fe}$, + All, + All-Fe) at each station after a 2 or 3 d incubation. Dashed lines: Redfield ratio of C:P. Values are mean $\pm \mathrm{SD}$ $(\mathrm{n}=3)$ ratio (16:1) at all the stations except for Stn 6 (Fig. 6). $\mathrm{N}: \mathrm{P}$ ratios in control treatments were 38.5:1 and 37.3:1 at Stns 7 and 8, respectively. In comparison, they were close to $16: 1$ in all the $\mathrm{P}$ addition treatments, and ranged from 16.4:1 to 22.5:1. A similar trend was also found at Stns 3 and 4 . However, N:P ratios in the + All and +All-Fe treatments were closer to the Redfield ratio than in the treatments with the addition of $\mathrm{P}$ only. $\mathrm{N}: \mathrm{P}$ ratios were 43.2:1 and 30.9:1 in control treatments

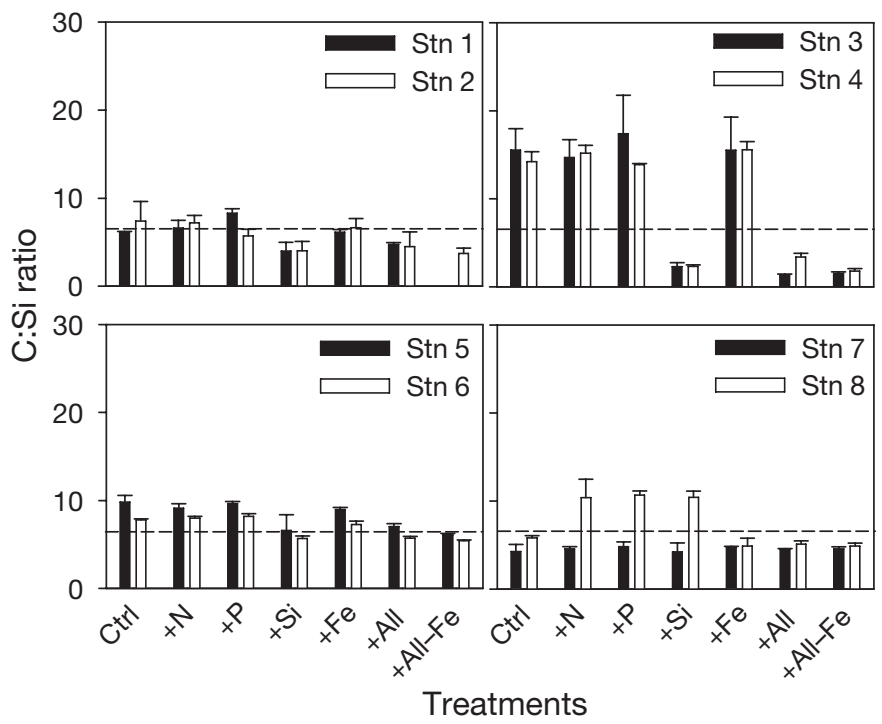

Fig. 5. Particulate organic carbon to biogenic silicon ratios for different nutrient addition treatments $\left(\mathrm{Ctrl},+\mathrm{N},+\mathrm{P},+\mathrm{Si}_{1}+\mathrm{Fe}\right.$, + All, +All-Fe) at each station after a 2 or 3 d incubation. Dashed lines: typical C:Si ratio for diatoms. Values are mean $\pm \mathrm{SD}(\mathrm{n}=3)$

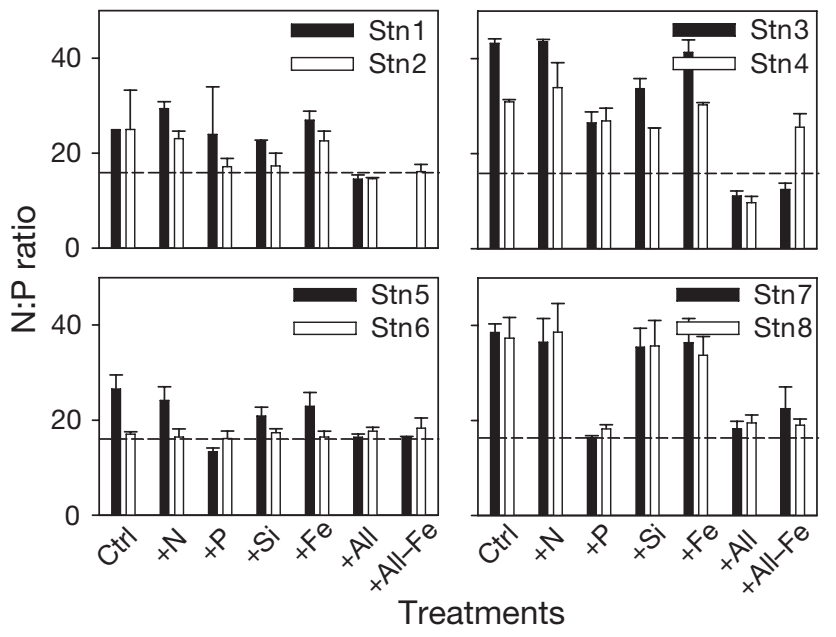

Fig. 6. Particulate organic nitrogen to phosphorus ratios for different nutrient addition treatments $\left(\mathrm{Ctrl},+\mathrm{N},+\mathrm{P}_{1}+\mathrm{Si}\right.$, $+\mathrm{Fe}_{1}+\mathrm{All},+\mathrm{All}-\mathrm{Fe}$ ) at each station after a 2 or $3 \mathrm{~d}$ incubation. Dashed lines: Redfield ratio of N:P. Values are mean \pm SD $(\mathrm{n}=3)$ 


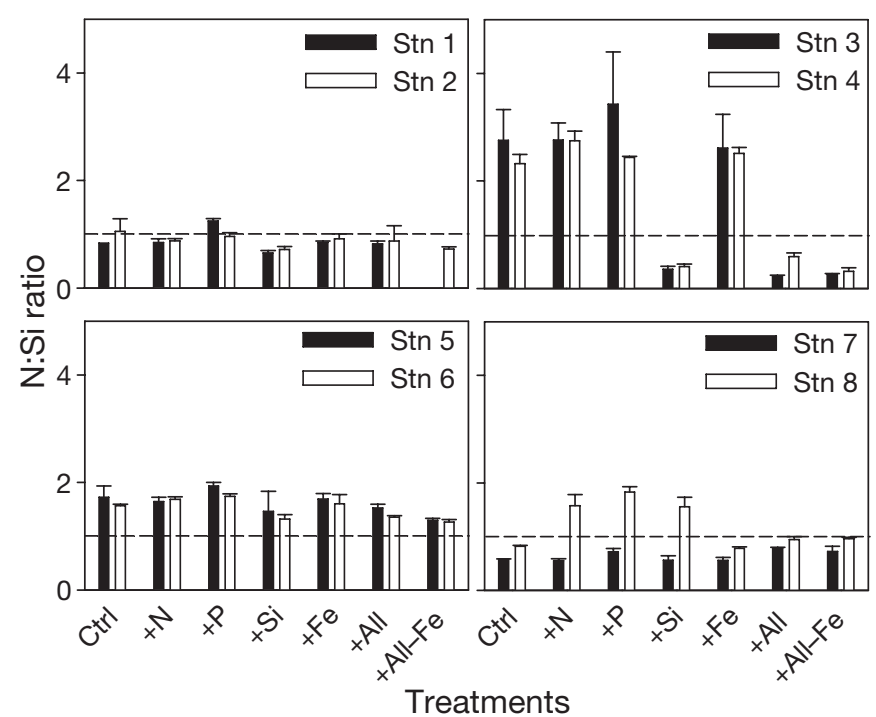

Fig. 7. Particulate organic nitrogen to biogenic silicon ratios for different nutrient addition treatments $\left(\mathrm{Ctrl},+\mathrm{N},+\mathrm{P}_{1}+\mathrm{Si}\right.$, $+\mathrm{Fe},+$ All, + All-Fe) at each station after a 2 or $3 \mathrm{~d}$ incubation. Dashed lines: typical N:Si ratio for diatoms. Values are mean $\pm \mathrm{SD}(\mathrm{n}=3)$

from Stns 3 and 4, and then decreased to 26.5:1 and 26.8:1 in the $+\mathrm{P}$ treatments. N:P ratios decreased further to $11.1: 1$ and $9.7: 1$ in treatments with the addition of all nutrients.

$\mathrm{N}: \mathrm{Si}$ ratios were almost constant among different nutrient addition treatments at the estuarine Stns 1, 2, 5 and 6 , and at Stn 7, but varied among treatments for Stns 3, 4, and 8 (Fig. 7). These ratios also varied considerably among different stations. N:Si ratios were generally low in all the estuarine samples, ranging from $0.72: 1$ to $1.94: 1$ at these stations. N:Si ratios were higher at Stns 3 and 4, ranging from 2.32:1 to 3.43:1 in all 4 treatments without $\mathrm{Si}$ addition. However, with $\mathrm{Si}$ addition, N:Si decreased remarkably (0.26:1 to 0.59:1).

As results obtained from Stns 3 and 4 were different from the other stations, i.e. phytoplankton showed the strongest response to the addition of all nutrients except $\mathrm{Fe}$, the increases in PON, POP, and BSi during the $2 \mathrm{~d}$ incubation were re-calculated. The initial PON, POP, and BSi were not available for Stns 1 or 2, so only results from Stns 3 to 8 were used. The newly produced N:P and N:Si ratios at the 6 stations were then compared (Fig. 8). There was little phytoplankton growth in some treatments (such as the controls) and thus little increase in PON, POP, and BSi, which produced a large variation in the production ratios. Therefore, only the ratios of +All and +All-Fe treatments, which had relatively high phytoplankton growth, are shown. As nutrients were enriched in these 2 treatments, the newly produced N:P and N:Si ratios were close to typical diatom ratios of $16: 1$ and 1:1 at most of
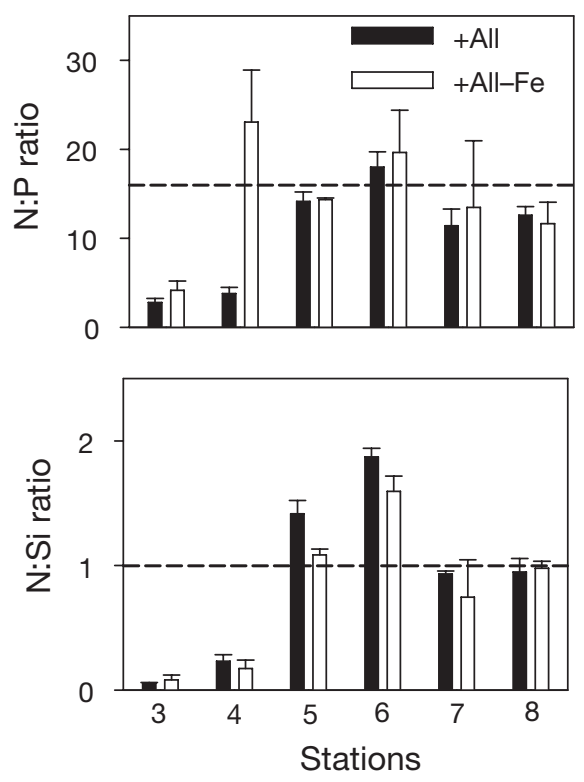

Fig. 8. N:P and N:Si production ratios for +All and + All-Fe addition treatments at Stns 3 to 8 . Dashed lines: Redfield ratio for $\mathrm{N}: \mathrm{P}$ and typical diatom ratio for $\mathrm{N}: \mathrm{Si}$, respectively. Values are mean $\pm \mathrm{SD}(\mathrm{n}=3)$

the 6 stations. N:P and N:Si ratios ranged from 11.4:1 to 19.7:1 and from $0.74: 1$ to $1.87: 1$, respectively, at Stns 5 to 8 . The most interesting results were observed at Stns 3 and 4 . N:P production ratios at these 2 stations were much lower than 16:1 (2.81:1 to 4.17:1), except for a very high production ratio of 23.0:1 that was observed for the +All-Fe treatment at Stn 4. Similarly, low ratios were also observed for N:Si production, which ranged from 0.05:1 to 0.23:1. Similar trends could also be observed for the newly calculated C:P and C:Si ratios (data not shown).

\section{DISCUSSION}

\section{Dissolved nutrient concentration on different sides of Hong Kong}

Concentrations of dissolved inorganic nutrients observed at the stations in our study were consistent with measurements taken in June and July from 1991 to 2000 (Yin 2002), with DIN concentrations of about 70,25 , and $<5 \mu \mathrm{M}$ for the estuarine, southern and eastern sides, respectively. DISi was comparable to DIN concentrations, and DIP concentrations were $<1 \mu \mathrm{M}$ in all areas. Therefore, it is the high riverine input from the Pearl River in the wet season (i.e. on average $22190 \mathrm{~m}^{3} \mathrm{~s}^{-1}$ in summer vs. $3340 \mathrm{~m}^{3} \mathrm{~s}^{-1}$ in winter) that brings abundant $\mathrm{N}$ and $\mathrm{Si}$ with relatively little $\mathrm{P}(60-$ $100 \mu \mathrm{M}$ DIN, 100-150 $\mu \mathrm{M}$ DISi, 0.5-1.0 $\mu \mathrm{M}$ DIP) (Zhao 1990, Zhang et al. 1999). 
This imbalance in riverine nutrient inputs, in combination with mixing processes with the oligotrophic South China seawater, results in the observed DIN and DISi concentration gradient from the western estuarine to the eastern side. Because the freshwater discharge moves eastward at the entrance of the estuary, due to the prevalent south-west wind in summer, high concentrations of $\mathrm{N}$ and $\mathrm{Si}$ were also observed at stations on the southern side. The freshwater flow to the southern side was further evidenced by the intermediate salinity and turbidity at Stns 7 and 8 . However, the freshwater input from the river had little effect on Stns 3 and 4, which were located on the eastern side with high salinity and low turbidity characteristics. As the South China Sea is oligotrophic (Wu et al. 2003), the water on the eastern side consequently had very low nutrients.

Temporal and spatial variation was also observed for DIN and DISi concentrations in the estuary. There was about a 3 wk interval between sampling at Stns 1/2 and Stns 5/6. The salinity at Stns 5 and 6 was much lower than at Stns 1 and 2, due to higher freshwater discharge in July. Therefore, it was the higher riverine input that contributed to the higher DIN and DISi concentrations observed at Stns 5 and 6, as the Pearl River is the main nutrient source for the estuary. On the other hand, Stns 2 and 6 were located upstream in the estuary relative to Stns 1 and 5, and hence nutrient concentrations at Stns 2 and 6 were higher. As there was a higher riverine input and higher water flow speed when water samples were collected from Stns 5 and 6 in July, the nutrient concentration difference between Stns 5 and 6 was much less than that between Stns 1 and 2. Thus, the temporal and spatial variation in nutrient concentrations in the estuarine area was mainly due to temporal variation of the riverine input, and to different distances of the various sampling sites from the Pearl River mouth. Further research at more stations and with more time points is needed for a more complete assessment of the spatial and temporal variability in this region.

\section{Nutrient limitation at different sites}

Chl a concentrations in the $+\mathrm{P}$ treatments were higher than in control treatments at most of the stations examined (i.e. Stns 1-4, 7 and 8). Particulate C:P and $\mathrm{N}: \mathrm{P}$ ratios were also much higher than the Redfield ratio for the treatments that had no P added. Although nutrient ratios themselves are not failsafe indicators of limitation, the different ratios in different treatments do, nevertheless, suggest nutrient limitation. Therefore, $\mathrm{P}$ appeared to be the limiting nutrient at most stations, including those on the western, southern, and also eastern sides. As described above, the Pearl River has high concentrations of DIN and DISi with low concentrations of DIP. Therefore, P limitation at stations on the western and southern sides was mainly due to disproportionately higher input of $\mathrm{N}$ and Si from the Pearl River, relative to $\mathrm{P}$. The highest DIN and DISi concentrations were observed at Stns 5 and 6, which resulted in the highest dissolved N:P ratio. However, it seems that phytoplankton were less limited by P at Stns 5 and 6 than at Stns 1 and 2, based on chl a concentrations in the control and $+\mathrm{P}$ treatments, as well as $\mathrm{C}: \mathrm{P}$ and $\mathrm{N}: \mathrm{P}$ ratios.

At the same time, the ratios of particulate organic $\mathrm{C}: \mathrm{P}$ and N:P were close to the Redfield ratio, especially at Stn 6. The exact reason for this remains unknown. One possibility is that phytoplankton at Stns 5 and 6 may be limited by some other nutrients (e.g. trace metals) that were not examined in our study. Another possibility is that dissolved organic $\mathrm{P}$ or particulate $\mathrm{P}$, which accounts for most of total $\mathrm{P}$ in estuarine waters (Conley et al. 1995, Zhang et al. 2004), can be used by phytoplankton at Stns 5 and 6, as species composition here was different from that at Stns 1 and 2 (Labry et al. 2002, Bjorkman \& Karl 2003).

The first possibility may be further supported by the fact that Si addition inhibited phytoplankton growth, as the final chl $a$ and particulate elemental contents were much lower in the $\mathrm{Si}$ addition treatments. This inhibition was observed for all 4 stations in the estuary, where background dissolved inorganic Si concentration was higher than at the other stations on the southern and eastern sides. The final DISi concentration was about $180 \mu \mathrm{M}$ after addition of $100 \mu \mathrm{M}$ Si at Stns 5 and 6. DISi For Stns 3 and 4, the DISi concentration there was $<5 \mu \mathrm{M}$ and phytoplankton growth was not inhibited after the addition of $100 \mu \mathrm{M}$ Si. Although initial DISi concentrations at Stns 7 and 8 were high and were therefore similar to that at Stn 1 (ca. $25 \mu \mathrm{M}$ ), and while both stations were also strongly affected by freshwater discharge, no inhibition was observed with the addition of $20 \mu \mathrm{M} \mathrm{Si}$.

Therefore, the high DISi concentration in all the Si addition treatments from the estuary resulted in growth inhibition of phytoplankton. The same Si stock was used for Si addition at all stations, and this same stock works well in the $\mathrm{f} / 2$ medium for our laboratory culture of several diatom species. Furthermore, it was impossible that $\mathrm{Si}$ at this concentration could have any toxic effects on the phytoplankton community dominated by diatoms. The $\mathrm{pH}$ values were also checked at the end of the experiment, and were comparable among different treatments at Stns 5 and 6. Thus it was hypothesized that $\mathrm{Si}$ has some indirect inhibiting effects on growth. It is possible that some trace metals other than $\mathrm{Fe}$, e.g. zinc, may be present at very low 
concentrations in the estuary. The high concentration of DISi could precipitate the trace metal and decrease its bioavailability. It is also possible that $\mathrm{Si}$ can compete with some low-concentration nutrient to be taken up by the phytoplankton. Wang \& Dei (2001) found that Se (a metalloid) uptake by the diatom Thalassiosira pseudonana was lowered with increasing ambient DISi concentration, as these nutrients may share the same transport pathway. Hence, a high concentration of DISi could inhibit the uptake of that nutrient and further inhibit phytoplankton growth. Both of these 2 possibilities suggest that some other micronutrients that were not examined in our study have a very low concentration and may be the potential limiting nutrient in this area. Further experiments need to be performed to explain this interesting phenomenon.

Previous research work in the Pearl River estuary indicated that $\mathrm{P}$ is most likely the limiting nutrient, followed by $\mathrm{N}, \mathrm{Si}$, and possibly $\mathrm{Fe}$, but the results depend on temporal and spatial scales. It has been found that primary production in various estuaries can be limited by either N, P, Si, or Fe (Murrell et al. 2002, Wu \& Chou 2003, Gameiro et al. 2004, Lewitus et al. 2004). Primary production can also be co-limited by more than 1 nutrient (Arrigo 2005). Furthermore, spatial and temporal variations of resource limitation have also been observed (Thompson 1998, Fisher et al. 1999). The P limitation in the Pearl River estuary observed in our study is consistent with previous research (Yin et al. 2001, 2004).

Although P limitation was also observed in another study conducted in this area, Zhang (2000) found that Fe addition had the strongest effect on phytoplankton growth and photosynthesis in this area. Our Fe addition treatments revealed no Fe limitation in the estuarine area. One possibility is that the time when the nutrient addition experiment was conducted was different. Our experiment was performed in the middle of the wet season (June and July 2004) while the study by Zhang (2000) was conducted at the end of September 1996. Organic ligands such as humic acids in the estuarine water might be different at different times, which might affect Fe speciation and phytoplankton growth in this area. Another possibility is that the phytoplankton species composition was different, as different species have different strategies to take up ambient Fe (Hutchins et al. 1999). In our study, the dominant phytoplankton species were Asterionella sp., Skeletonema sp., Pseudonitzschia sp., and Chaetoceros sp. at Stns 1 and 2, and Thalassiosira sp. and Skeletonema sp. at Stns 5 and 6 (Table 2). Chaetoceros sp. and Coscinodiscus sp. were found to be the dominant species in the study by Zhang (2000).

Although P limitation was also observed at stations on the eastern side of Hong Kong, chl a concentrations increased more significantly after the addition of all nutrients and all nutrients except $\mathrm{Fe}(\mathrm{p}<0.05)$. As concentrations of nutrients were all very low, it is possible that phytoplankton were potentially limited by several nutrients, not simultaneously, but one after the other in sequence. This is quite distinct from the 3 different types of nutrient co-limitation reviewed by Arrigo (2005). Phytoplankton limitation may shift from one to another nutrient as the primary limiting nutrient is exhausted. $\mathrm{P}$ was the proximate limiting nutrient at these 2 stations. After enrichment of $\mathrm{P}$, phytoplankton must have then been quickly limited by another nutrient, as its growth induction was less than those in +All and +All-Fe treatments. The fact that both C:Si and $\mathrm{N}: \mathrm{Si}$ ratios were much higher than the typical ratio in the control treatments (these ratios may even be underestimated if there was any LSi interference), and significantly decreased $(p<0.05)$ after addition of $\mathrm{Si}_{\text {, }}$ suggested that $\mathrm{Si}$ followed $\mathrm{P}$ as the limiting nutrient for growth of the dominant diatoms at Stns 3 and 4. This was further evidenced by the notable Si uptake (i.e. low particulate C:Si ratio) in the +Si treatment without any growth, as phytoplankton was still limited by $\mathrm{P}$, and the biomass increased only when $\mathrm{P}$ limitation was relieved.

As chl a concentrations in the + All-Fe treatments were lower than +All treatments, especially for Stn 4, Fe might also have limited or co-limited phytoplankton growth. However, N:Si ratios were similar for both +All and +All-Fe treatments, indicating that phytoplankton cells were not more silicified without Fe additions. This result is different from that of Hutchins \& Bruland (1998). The DIN concentration was low and so was biomass (i.e. low dissolved organic $\mathrm{N}$ production), and therefore $\mathrm{N}$ could also be the potential limiting nutrient either before or after Fe. As nutrients were balanced around the Redfield ratio, a shift from one nutrient limitation to another may occur, depending on small changes in the balance between all the nutrients.

The hypothesis that phytoplankton at Stns 3 and 4 were first limited by $\mathrm{P}$ and $\mathrm{Si}$ was also supported by the much lower than typical values of the re-calculated N:P and N:Si ratios (around 16:1 and 1:1, respectively for diatoms) in both the +All and +All-Fe treatments. At the same time, the cellular $\mathrm{N}$ as $\mathrm{N}: \mathrm{C}$ was still close to the Redfield ratio. Thus, the low recalculated N:P and N:Si ratios were not due to the decrease in $\mathrm{N}$ uptake, but due to the much higher uptake of $\mathrm{P}$ and $\mathrm{Si}_{1}$ which resulted in the higher cellular $\mathrm{P}$ and $\mathrm{Si}$ content (i.e. high $\mathrm{P}: \mathrm{C}$ and $\mathrm{Si}: \mathrm{C}$ ratios). These ratios were in excess of what the cells would likely require to support their growth. This can be referred to as 'luxury uptake' when nutrient limitation was relieved. Luxury uptake of $\mathrm{P}$ and $\mathrm{Si}$ has been observed in previous studies (Martin-Jezequel 
2000, Vincent 2001, Tozzi et al. 2004). It was found that the amount of stored $\mathrm{Si}$ was sufficient for the later synthesis of an entire cell after giving Si-starved Thalossiosira weissflogii a pulse of silicic acid (Martin-Jezequel 2000 and references therein), since excess nutrients can be stored in the vacuole (Raven 1997, Tozzi et al. 2004). Furthermore, the luxury uptake of $\mathrm{P}$ and Si may be due to increased uptake rate (i.e. increase in the maximum uptake rate or the decrease in the half-saturation constant, or both) under nutrient limited conditions (Fu et al. 2005).

In conclusion, we found that the DIN and DISi concentrations in the coastal waters of Hong Kong decreased from the western estuarine, southern and finally to the eastern side. This gradual decrease in $\mathrm{N}$ and Si indicated that the Pearl River discharge serves as the main source of $\mathrm{N}$ and $\mathrm{Si}$ to coastal waters in Hong Kong, and that the oligotrophic South China Sea has the greatest influence farthest away from the river, on the eastern side. Accordingly, temporal and spatial variation was observed for the nutrient concentrations on the western side. Higher DIN and DISi concentrations were observed at the stations closer to the Pearl River mouth, or when there was a higher riverine input. As the P concentration was also low in the freshwater, the DIP concentration was kept relatively constant at all the 8 stations examined. Due to the imbalanced input of $\mathrm{N}$ and $\mathrm{Si}$ to the western and southern waters as compared to $\mathrm{P}$, the phytoplankton were mainly limited by $\mathrm{P}$ at most of the stations examined. However, P limitation was less obvious at Stns 5 and 6 on the western side (with a higher riverine input), which may have been due to the utilization of particulate $\mathrm{P}$ or dissolved organic $\mathrm{P}$, or limitation by some other micronutrients not examined in our study. In the coastal water on the eastern side, the phytoplankton were limited by several nutrients sequentially following the order: $\mathrm{P}>\mathrm{Si}>\mathrm{N} / \mathrm{Fe}$, and 'luxury uptake' of $\mathrm{P}$ and $\mathrm{Si}$ was observed when these nutrients were enriched. All the nutrient concentrations on the eastern side were very low, and a shift in limitation from one nutrient to another may be frequent as a result of some sporadic nutrient input. Furthermore, Si inhibition of cell growth in the estuary should be further examined in the future-this may be due to the complexation of silicate with other low concentration trace metals, or to uptake competition between Si and other nutrients.

Acknowledgements. We thank the anonymous reviewers for their comments on our study, which was supported by the Natural Science Foundation of China (40229008), Competitive Earmarked Research Grants from the Hong Kong Research Grants Council (N_HKUST603/01), and US National Science Foundation (OCE 0327724 and OCE 0423418).

\section{LITERATURE CITED}

Armstrong FAJ, Stearns CR, Strickland JDH (1967) The measurement of upwelling and subsequent biological processes by means of the Technicon AutoAnalyzer and associated equipment. Deep-Sea Res 14:381-389

Arrigo KR (2005) Marine microorganisms and global nutrient cycles. Nature 437:349-355

Bjorkman KM, Karl DM (2003) Bioavailability of dissolved organic phosphorus in the euphotic zone at station ALOHA, North Pacific Subtropical Gyre. Limnol Oceanogr 48: 1049-1057

Boyd P, LaRoche J, Gall M, Frew R, McKay RML (1999) Role of iron, light, and silicate in controlling algal biomass in subantarctic waters SE of New Zealand. J Geophys Res 104:13395-13408

Brzezinski MA, Nelson DM (1995) The annual silica cycle in the Sargasso Sea near Bermuda. Deep-Sea Res I 42: $1215-1237$

Conley DJ, Smith WM, Cornwell JC, Fisher TR (1995) Transformation of particle-bound phosphorus at the land sea interface. Estuar Coast Shelf Sci 40:161-176

de Baar HJW, de Jong JTM, Nolting RF, van Leeuwe MM, Timmermans KR, Templin M, Rutgers van der Loeff MM, Sildam J (1999) Low dissolved Fe and the absence of diatom blooms in remote Pacific waters of the Southern Ocean. Mar Chem 66:1-34

Dugdale RC, Wilkerson FP, Minas HJ (1995) The role of a silicate pump in driving new production. Deep-Sea Res I 42: 697-719

Fisher TR, Gustafson AB, Sellner K, Lacouture R and 6 others (1999) Spatial and temporal variation of resource limitation in Chesapeake Bay. Mar Biol 133:763-778

Fu FX, Zhang YH, Bell PRF, Hutchins DA (2005) Phosphate uptake and growth kinetics of Trichodesmium (Cyanobacteria) isolates from the North Atlantic Ocean and the Great Barrier Reef, Australia. J Phycol 41:62-73

Gameiro C, Cartaxana P, Cabrita MT, Brotas V (2004) Variability in chlorophyll and phytoplankton composition in an estuarine system. Hydrobiologia 525:113-124

Hager SW, Gordon LI, Park PK (1968) A practical manual for use of the Technicon Autoanalyzer in seawater nutrient analyses [OSU Ref 68-33]. Department of Oceanography, Oregon State University, Corvallis

Hutchins DA, Bruland KW (1998) Iron-limited diatom growth and Si:N uptake ratios in a coastal upwelling regime. Nature 393:561-564

Hutchins DA, Witter AE, Butler A, Luther GW (1999) Competition among marine phytoplankton for different chelated iron species. Nature 400:858-861

Labry C, Herbland A, Delmas D (2002) The role of phosphorus on planktonic production of the Gironde plume waters in the Bay of Biscay. J Plankton Res 24:97-117

Lebo ME, Sharp JH (1992) Phosphorus distributions along the Delaware: an urbanized coastal plain estuary. Estuaries 16:291-302

Lewitus AJ, Kawaguchi T, DiTullio GR, Keesee JDM (2004) Iron limitation of phytoplankton in an urbanized vs. forested southeastern US salt marsh estuary. J Exp Mar Biol Ecol 298:233-254

Mallin MA, Paerl HW (1992) Effects of variable irradiance on phytoplankton productivity in shallow estuaries. Limnol Oceanogr 37:54-62

Martin JH, Fitzwater SE (1988) Iron deficiency limits phytoplankton growth in the north-east Pacific subarctic. Nature 331:341-343

Martin-Jezequel V, Hildebrand M, Brzezinski MA (2000) Sili- 
con metabolism in diatoms: implications for growth. J Phycol 36:821-840

Mills MM, Ridame C, Davey M, La Roche J, Geider RJ (2004) Iron and phosphorus co-limit nitrogen fixation in the eastern tropical North Atlantic. Nature 429:292-294

Murrell MC, Stanley RS, Lores EM, DiDonata GT, Smith LM, Flemer DA (2002) Evidence that phosphorus limits phytoplankton growth in a Gulf of Mexico estuary: Pensacola Bay, Florida, USA. Bull Mar Sci 70:155-167

Parsons TR, Maita Y, Lalli CM (1984) A manual of chemical and biological methods for seawater analysis. Pergamon Press, New York

Ragueneau O, Savoye N, Del Amo Y, Cotten J, Tardiveau B, Leynaert A (2005) A new method for the measurement of biogenic silica in suspended matter of coastal waters: using $\mathrm{Si}$ :Al ratios to correct for the mineral interference. Cont Shelf Res 25:697-710

Raven JA (1990) Predictions of Mn and Fe use efficiencies of phototrophic growth as a function of light availability for growth and of C assimilation pathway. New Phytol 116: $1-18$

Raven JA (1997) The vacuole: a cost-benefit analysis. Adv Bot Res 25:59-86

Slawyk G, MacIsaac JJ (1972) Comparison of two automated ammonium methods in a region of coastal water upwelling. Deep-Sea Res 19:521-524

Solorzano L, Sharp JH (1980) Determination of total dissolved phosphorus and particulate phosphorus in natural waters. Limnol Oceanogr 25:756-760

Strickland JDH, Parsons TR (1968) A practical handbook of seawater analysis. Fisheries Research Board of Canada, Ottawa

Thompson PA (1998) Spatial and temporal patterns of factors influencing phytoplankton in a salt wedge estuary, the Swan River, Western Australia. Estuaries 21:801-817

Tozzi S, Schofield O, Falkowski P (2004) Historical climate change and ocean turbulence as selective agents for two key phytoplankton functional groups. Mar Ecol Prog Ser 274:123-132

Tyrrell T (1999) The relative influences of nitrogen and phosphorus on oceanic primary production. Nature 400: 525-531

Vincent WJ (2001) Nutrient partitioning in the upper Canning River, Western Australia, and implications for the control of cyanobacterial blooms using salinity. Ecol Eng 16: $359-371$

Editorial responsibility: Otto Kinne (Editor-in-Chief), Oldendorf/Luhe, Germany
Wang WX, Dei RCH (2001) Metal uptake in a coastal diatom influenced by major nutrients (N, P, and Si). Water Res 35: 315-321

Wood ED, Armstrong FAJ, Richards FA (1967) Determination of nitrate in seawater by cadmium-copper reduction to nitrite. J Mar Biol Assoc UK 47:23-31

Wu HT, Chou TL (2003) Silicate as the limiting nutrient for phytoplankton in a subtropical eutrophic estuary of Taiwan. Estuar Coast Shelf Sci 58:155-162

Wu JF, Chung SW, Wen LS, Liu KK, Chen YL, Chen HY, Karl DM (2003) Dissolved inorganic phosphorus, dissolved iron, and Trichodesmium in the oligotrophic South China Sea. Global Biogeochem Cycles 17, doi: 10.1029/ 2002GB001924

Yin K (2002) Monsoonal influence on seasonal variations in nutrients and phytoplankton biomass in coastal waters of Hong Kong in the vicinity of the Pearl River estuary. Mar Ecol Prog Ser 245:111-122

Yin K, Qian PY, Chen JC, Hsieh DPH, Harrison PJ (2000) Dynamics of nutrients and phytoplankton biomass in the Pearl River estuary and adjacent waters of Hong Kong during summer: preliminary evidence for phosphorus and silicon limitation. Mar Ecol Prog Ser 194:295-305

Yin K, Qian PY, Wu MCS, Chen JC, Huang L, Song X, Jian W (2001) Shift from $\mathrm{P}$ to $\mathrm{N}$ limitation of phytoplankton growth across the Pearl River estuarine plume during summer. Mar Ecol Prog Ser 221:17-28

Yin K, Song X, Sun J, Wu MCS (2004) Potential P limitation leads to excess $\mathrm{N}$ in the Pearl River estuarine coastal plume. Cont Shelf Res 24:1895-1907

Yung YK, Wong CK, Qian PY (2001) Long-term changes in water quality and phytoplankton characteristics in Port Shelter, Hong Kong, from 1988-1998. Mar Pollut Bull 42:981-992

Zhang J (2000) Evidence of trace metal limited photosynthesis in eutrophic estuarine and coastal waters. Limnol Oceanogr 45:1871-1878

Zhang J, Yu ZG, Wang JT, Ren JL, Chen HT, Xiong H, Dong LX, Xu WY (1999) The subtropical Zhujiang (Pearl River) Estuary: nutrient, trace species and their relationship to photosynthesis. Estuar Coast Shelf Sci 49:385-400

Zhang JZ, Fischer CJ, Ortner PB (2004) Potential availability of sedimentary phosphorus to sediment resuspension in Florida Bay. Global Biogeochem Cycles 18, doi: 10.1029/ 2004GB002255

Zhao H (1990) Evolution of the Pearl River Estuary. Ocean Press, Beijing

Submitted: August 1, 2005; Accepted: January 12, 2006

Proofs received from author(s): July 18, 2006 